\title{
Efficacy of Zinc Phosphide and Strychnine for Black-tailed Prairie Dog Control
}

\author{
DANIEL W. URESK, RUDY M. KING, ANTHONY D. APA, AND RAYMOND L. LINDER
}

\section{Abstract}

Three rodenticide treatments, zinc phosphide (prebaited) and strychnine (both with and without prebait), were evaluated immediately following treatment for efficacy of controlling blacktailed prairie dogs in western South Dakota. Active prairie dog burrows were reduced $95 \%$ with zinc phosphide, $83 \%$ with strychnine (prebaited), and $45 \%$ with strychnine without prebait. Zinc phosphide was the most effective in reducing active burrows of prairie dogs.

The black-tailed prairie dog (Cynomys ludovicianus) inhabits prairie regions of the western United States from Canada to Mexico, east of the Rocky Mountains and west of the tall grass prairie (Hall 1981). Prairie dog towns often encompass vast areas. Because prairie dog feeding and burrowing activities conflict directly with interests of ranchers and range managers, widespread control programs using rodenticides were begun in the late 1800 's on the Great Plains (Merriam 1902). Prairie dogs are still considered a problem when they compete with cattle for forage plants (Hansen and Gold 1977). Most recent prairie dog control programs on federal, state, and private lands consist of poisoning prairie dogs with zinc phosphide on rolled oats after prebaiting with rolled oats (Schenbeck 1982).

Zinc phosphide has been widely used as a rodenticide since 1942-43 when strychnine supplies became limited during World War II (Timm 1983). More recently, zinc phosphide formulation and application rates have been developed for use in prairie dog control (Tietjen 1976). Strychnine has been used for prairie dog control since the late 1800's (Merriam 1902). These two rodenticides are widely used for prairie dog control throughout the western United States. However, comparative information of these two rodenticides for effective control of black-tailed prairie dogs has not been reported. This investigation was undertaken to compare the efficacy of rodenticides zinc phosphide (pre-baited) and strychnine with and without prebaiting for controlling black-tailed prairie dogs in western South Dakota.

\section{Study Area}

The study area was approximately $13 \mathrm{~km}$ south of Wall on the Buffalo Gap National Grasslands and Badlands National Park in west-central South Dakota. Climate was semiarid-continental and characterized by cold winters and hot summers. The average annual precipitation, based on climatological information over a 12-year period (1972-1983) from the weather station at Cedar Pass Visitor Center, Badlands National Park, was $40 \mathrm{~cm}$. Most precipitation fell during the growing season as high-intensity thunder-

Uresk and King are research biologist and biometrician, respectively, with the Rocky Mountain Forest and Range Experiment Station. Uresk is in Rapid City, South Dakota, in cooperation with the South Dakota School of Mines and Technology; King is at the Station's headquarters in Fort Collins, in cooperation with Colorado State University; Apa is a graduate research assistant, and Linder, now retired, formerly a unit leader, South Dakota Cooperative Fish and Wildlife Research Unit, South Dakota State University, Brookings.

This publication reports research involving pesticides. It does not contain recommendations for their use, nor does it imply that the uses discussed here have been registered. All uses of pesticides must be registered by appropriate state and/or federal agencies before they can be recommended.

Special thanks is given to Deborah D. Paulson for data collection, computer analyses'and reviews of several drafts. Thanks are also extended to the South Dakota Department of Game, Fish and Parks for providing vehicles, equipment, and personnel for rodenticide application; Nebraska National Forest and Badlands National Park for assisting with rodenticide application and for providing study areas. Partial funding of this study was provided by the National Pesticide Impact Assessment Program (NAPIAP).

Manuscript accedted 25 November 1985. showers, which produced a wide range of amounts and intensities of rain for any given location. The mean annual temperature was $10^{\circ} \mathrm{C}$, ranging from $-5^{\circ} \mathrm{C}$ in January to $26^{\circ} \mathrm{C}$ in July.

Dominant grasses on the study area were blue grama (Bouteloua gracilis), buffalograss (Buchloe dactyloides), needleleaf sedge (Carex eleocharis), and western wheatgrass (Agropyron smithii). Scarlet globemallow (Sphaeralcea coccinea), prostrate bigbract verbena (Verbena bracteata), Patagonia Indianwheat (Plantago patagonica), and prairie dogweed (Dyssodia papposa) were major forbs.

Bison (Bison bison), pronghorn (Antilocapra americana), and mule deer (Odocoileus hemionus) were large herbivores which grazed in the Badlands National Park throughout the year. Cattle on the National Grasslands grazed the area from mid-May to the last of October each year. Stocking levels varied depending upon moisture and available forage: Mule deer and pronghorn grazed the National Grassland throughout the year.

\section{Methods}

Eightcen study sites were established on 15 prairie dog colonies that ranged in area from approximately 12 ha to 283 ha. Nine sites were untreated and 9 sites were treated with the rodenticides zinc phosphide (prebaited) and strychnine, with and without prebaiting; thus, each rodenticide treatment had 3 control and 3 treated sites. The 3 rodenticide treatments were clustered into 3 separate groups, approximately 13 and $16 \mathrm{~km}$ apart. Zinc phosphide treatments were applied to sites in the Badlands National Park because of administration constraints against the use of strychnine in such areas. The other 2 treatment groups, strychnine with and without prebaiting with steam-rolled oats, were assigned randomly to the 2 remaining clusters on the National Grasslands.

Steam-rolled oats from the U.S. Fish and Wildlife Service's Pocatello Supply Depot were used for both prebait an carrier. A $2.0 \%$ by weight active zinc phosphide and $1.5 \%$ Alcolec $S^{\prime}$ adhesive were applied to the oats. Strychnine alkaloid was applied to the oats as $0.5 \%$ by weight. Nontreated oats were applied as prebait for zinc phosphide and for 1 of the strychnine treatments during September 20-21, 1983. Active rodenticides on steam-rolled oats were applied during September 22-24, 1983.

Pretreatment counts for active prairie dog burrows were taken on all sites 1 week before application of rodenticides. Posttreatment sampling on all sites began on the fourth day after rodenticides were applied.

Black-tailed prairie dog burrows within $100-\times 100$-m grids on all sites, including controls, were plugged with soil before and after treatment with rodenticides. The total number reopened in $\mathbf{4 8}$ hours was recorded (Tietjen and Matschke 1982). Data were analyzed as mean number of active prairie dog burrows per site.

\section{Statistical Evaluation}

Analysis of covariance was used to compare each treated group (cluster) of sites with its respective control group. Pretreatment observations were used as covariates. Effect of treatment was estimated as the covariance-adjusted difference between treated and control sites for each rodenticide. After rejecting the hypothe-

\footnotetext{
The use of Alcolec S (American Lecithin Co., Inc.) name is for the benefit of the reader; such use does not constitute an official endorsement or approval of any service or product by the U.S. Department of Agriculture to the exclusion of others that may be suitable.
} 
sis of no treatment effect, and determining that variance among clusters was heterogenous, each treatment effect contrast was evaluated for significance based on a variance estimated only from the sites in each cluster. Comparisons among rodenticides were produced by forming pairwise contrasts of individual rodenticide treatment contrasts. Randomization procedures (Edgington 1980, Romesburg 1981) based on 10,000 random permutations of the data pairs among treatment groups were used to estimate statistical significance of the various contrasts.

Because omission of any effect due to poisoning was considered more serious than the potential incorrect declaration of a significant treatment effect, Type II error protection was produced by testing each contrast individually. However, some Type I error protection was afforded by testing individual contrasts only after first observing a significant $(P=0.10)$ overall test of treatment differences using analysis of covariance (Carmer and Swanson 1973). Individual contrasts were considered biologically significant at $\boldsymbol{P}=\mathbf{0 . 2 0}$. Although admittedly unconventional, for the number of sites available for study, this significance criterion produces a power (probability of detecting a true difference) of approximately 0.80 for a contrast twice as large as its standard error. This was considered a reasonable combination of Type I and Type II error protection for this study (Carmer 1976).

\section{Results and Discussion}

Adjusted means for the zinc phosphide treatment showed a $95 \%$ reduction in active burrows $(P=0.017)$ of the black-tailed prairie dog when compared to the control (Table 1). The application of

Table 1. Active burrows of black-tailed prairie dogs (mean/ha \pm standard error) for pre- and posttreatment with rodenticides on treated and control sites. Pretreatment was used as covariate to obtain adjusted posttreatment means.

\begin{tabular}{|c|c|c|c|c|}
\hline Treatment & $\begin{array}{c}\text { Pre- } \\
\text { treatment }\end{array}$ & $\begin{array}{c}\text { Post- } \\
\text { treatment }\end{array}$ & $\begin{array}{c}\text { Adjusted } \\
\text { effect }\end{array}$ & $\begin{array}{l}\text { Significance } \\
\text { level (control } \\
\text { vs. treated) }\end{array}$ \\
\hline \multicolumn{5}{|c|}{ Zinc phosphide (with prebait) } \\
\hline $\begin{array}{l}\text { Treated } \\
\text { Control }\end{array}$ & $\begin{array}{l}55 \pm 16 \\
59 \pm 9\end{array}$ & $\begin{array}{r}2 \pm 1 \\
49 \pm 10\end{array}$ & $-45.5 \pm 8.8$ & 0.017 \\
\hline $\begin{array}{c}\text { Strychnine } \\
\text { Treated } \\
\text { Control }\end{array}$ & $\begin{array}{l}42 \pm 6 \\
25 \pm 6\end{array}$ & $\begin{array}{l}15 \pm 10 \\
24 \pm 1\end{array}$ & $-14.5 \pm 8.3$ & 0.164 \\
\hline $\begin{array}{c}\text { Strychnine } \\
\text { Treated } \\
\text { Control }\end{array}$ & $\begin{array}{l}\text { rebait) } \\
55 \pm 7 \\
54 \pm 21\end{array}$ & $\begin{array}{r}7 \pm 3 \\
30 \pm 13\end{array}$ & $-23.5 \pm 6.5$ & 0.035 \\
\hline
\end{tabular}

strychnine without prebaiting reduced active burrows $45 \%(P=0.164)$. Adjusted means for strychnine (prebaited) showed a reduction in active burrows of $83 \%(P=0.035)$.

Comparisons among rodenticides showed zinc phosphide was more effective in reducing active prairie dog burrows than was strychnine without prebaiting $(P=0.034)$ and strychnine with prebaiting ( $P=0.075$ ). However, there was no difference in reduction of active burrows between strychnine with and without prebaiting ( $P=0.391$ ).

Among the 3 rodenticide treatments tested, application of zinc phosphide bait with prebaiting was the most effective in reducing active burrows of black-tailed prairie dogs. Tietjen and Matschke
(1982) reported a $96 \%$ reduction in prairie dog activity with the use of zinc phosphide on the Pine Ridge Indian Reservation in southwestern South Dakota. Prebaiting was more effective than without prebaiting when zinc phosphide was used as a control agent for black-tailed prairie dogs (Tietjen 1976). Strychnine without prebaiting was the least effective of the 3 rodenticide treatments in our study, and was more variable in reducing active burrows of prairie dogs. Furthermore, zinc phosphide has been considered the least damaging to nontarget animals (Bell and Dimmick 1975, Schitoskey 1975, Tretjen 1976), when compared to strychnine (Rudd and Genelly 1956, Schitoskey 1975, Hegdal et al. 1981, Wood 1965, Hegdal and Gatz 1977). Thus, the rodenticide zinc phosphide should be highly considered for black-tailed prairie dog control on western rangelands because of its efficacy and lesser impacts on nontarget animals.

\section{Literature Cited}

Bell, H.B., and R.W. Dimmick. 1975. Hazards to predators feeding on prairie voles killed with zinc phosphide. J. Wildl. Manage. 9:816-819.

Cramer, S.G. 1976. Optimal significance levels for application of the least significant difference in crop performance trials. Crop Sci. 16:95-99.

Cramer, S.G., and M.R. Swanson. 1973. An evaluation of ten pairwise multiple comparison procedures by Monte Carlo methods. J. Amer. Statis. Ass. 68:66-74.

Edgington, E.S. 1980. Randomization tests. Marcel Dekker, Inc., New York.

Hall, E. 1981. The mammals of North America. Vol. 1. John Wiley and Sons, New York.

Hansen, R.M., and I.K. Gold. 1977. Black-tailed prairie dogs, desert cottontails and cattle trophic relations on shortgrass range. J. Range Manage. 30:210-213.

Hegdal, P.O., and T.L. Gatz. 1977. Hazards to seedeating birds and other wildlife associated with surface strychnine baiting for Richardson's ground squirrels. EPA report under Interagency Agreement EPA-IAGD4-0449.

Hegdal, P.L., T.A. Gatz, and E.C. Fite. 1981. Secondary effects of rodenticides on mammalian predators. p. 1781-1793. In: J.A. Chapman and D. Pursley, eds. The Worldwide Furbearer Conference Proceedings.

Merriam, D. 1902. The prairie dog of the Great Plains. p. 257-270. In: Yearbook of the United States Department of Agriculture, Gov. Print. Off., Washington, D.C.

Romesburg, C. 1981. Randomization tests. Resource Evaluation Newsletter. p. 1-3. Tech. Article 1. USDI-BLM, Denver, Fed. Cntr., Denver, Colo.

Rudd, R.L., and R.E. Genelly. 1956. Pesticides: their use and toxicity in relation to wildlife. Calif. Fish and Game Bull. No. 7.

Schenbeck, G.L. 1982. Management of black-tailed prairie dogs on the National Grasslands, p. 207-217. In: R.M. Timm and R.J. Johnson, eds., Fifth Great Plains Wildl. Damage Control Workshop. Proc. Oct. 13-15, 1981. Univ. Nebraska, Lincoln.

Schitoskey, F. 1975. Primary and secondary hazards of three rodenticides to kit fox. J. Wildl. Manage. 39:416-418.

Tietjen, H.P. 1976. Zinc phosphide-Its development as a control agent for black-tailed prairie dogs. U.S. Dep. Int., Fish and Wildl. Serv. Spec. Sci. Rep.-Widl. 195

Tietjen, H.P., and G.H. Matschke. 1982. Aerial prebaiting for management of prairie dogs with zinc phosphide. J. Wildl. Manage. 46:1108-1112.

Timm, R.M. 1983. Description of active ingredients. p. G-31-G-77. In: R. M. Timm, ed. Prevention and control of wildlife damage. Great Plains Agr. Council, Wildl. Res. Comm. Nebraska Coop. Ext., Lincoln.

Wood, J.E. 1965. Response of rodent populations to controls. J. Wildl. Manage. 29:425-427. 